\title{
Detection of gene expression and enzyme activity of Cytochrom P450 arom (aromatase) in preantral and early antral bovine follicles depending on culture conditions in vitro
}

\begin{abstract}
This study reveals that cultivation of preantral and early antral $(<500 \mu \mathrm{m})$ follicles in culture medium containing FCS results in an expression of cytochrome P450 arom. (aromatase). The enzymatic activity of aromatase, measured in terms of the estradiol synthesis, was proved to be present in follicles greater than $100 \mu \mathrm{m}$, could further be stimulated by FSH in follicles greater than $300 \mu \mathrm{m}$ diameter. The enzyme protein and the gene expression were studied by means of western blot and immunohistochemistry as well as by means of realtime PCR. Neither the protein nor the corresponding mRNA could be found in uncultivated follicles and in FCS-free cultivated follicles. Estradiol synthesis could not be determined under FCS-free conditions. The expression of the FCS effect was dependent on the follicle size.
\end{abstract}

Key Words: Cattle, Preantrale Follicle, FSH, Estradiol, Aromatase, Culture

\section{Zusammenfassung}

Titel der Arbeit: Bestimmung der Genexpression des Proteins und der Enzymaktivität von Cytochrom P450 arom (Aromatase) in preantralen und frühen antralen Follikeln des Rindes in Abhängigkeit von den Kulturbedingungen in vitro

Diese Studie zeigt, dass die Kultivierung von präantralen und frühen antralen $(<500 \mu \mathrm{m})$ Follikeln in FKShaltigem Kulturmedium zur Expression von Cytochrome P450 arom (Aromatase) führt. Die Enzymaktivität von Aromatase, gemessen an Hand der Estradiol Synthese, konnte in Follikeln größer als $100 \mu$ m Durchmesser nachgewiesen und in Follikeln größer als $300 \mu$ durch FSH zusätzlich stimuliert werden. Das Enzymprotein und die Genexpression wurden mittels Western Blot und Immunhistochemie sowie mittels realtime-PCR untersucht. Weder das Protein noch die entsprechende mRNA konnten in unkultivierten Follikeln oder in FKSfrei kultivierten Follikeln gefunden werden. Eine Estradiolsynthese war unter FKS-freien Kulturbedingungen nicht nachweisbar. Die Expression der FKS-Wirkung war von der Follikelgröße abhängig.

Schlüsselwörter: Rind, Präantrale Follikel, FSH, Estradiol, Aromatase, Zellkultur

\section{Introduction}

The ovarian follicle is the structural and functional unit of the mammalian ovary. It consists of an oocyte, surrounding granulosa cells, a basement membrane and the associated thecal cells (KANITZ, 2003; HARRISON and WEIER, 1977). Follicular and oocyte development in situ rendering fertilization capability, depends upon complex regulatory interactions between the different cell types in the follicle (MIHM, 2001). These interactions create a unique and progressively shifting environment during the development of the follicle and the oocyte. At any stage a normal follicle may develop or proceed towards atresia. There exists a high possibility of atresia for most follicles.

Most oocytes of the mammalian ovary are within the preantral follicles. An effective possibility of these oocytes maturing up to the fertilization capability would develop a 
great potential for many bio-technical methods. For small mammals (mice), methods have been described where live offsprings have been produced (EPPIG and SCHROEDER, 1989; SPEARS et al., 1994) using oocytes from preantral follicles. For large mammals, such as cattle, these methods cannot be easily adopted (WU et al., 2001). Reasons for this can be found in the considerably longer developmental time of the follicles and more complex regulatory events. Approximately 80-100 days are necessary for the growth of an activated primordial follicle up to the preovulatory follicle stage (LUSSIER et al., 1987; KANITZ et al., 2001).

FSH and LH play a central role in the ovarian follicle development, especially in activation, growth, atresia and ovulation. Different intra-gonadal factors like IGF-I, EGF, TGF, Interleukin, Inhibin and Aktivin modulate the effect of gonadotrophins or influence the cell functions independently (ADASHI, 1993; FINDLAY, 1993; GREENWALD and ROY, 1994; ROY and GREENWALD, 1996; EPPIG et al., 1998). Only a few partly contradictory information about the role of the steroids and particularly the estradiol is available at present. Some authors reconcile in their opinion that there is only a subordinate effect of steroids on the follicle development. There are some other works that describe a paracrine influence on follicles after the time of activation [mouse: (FEHRENBACH et al., 1998; SPEARS et al., 1998) primates: (KOERING et al., 1994)]. The detection of steroid receptors, however, for instance [humans: (REVELLI et al., 1996); Sheep: (TOMANEK et al., 1997)] and the detection of steroidal enzymes [rat: (GELETY and MAGOFFIN, 1997)] or the steroid synthesis [cattle: (PÖHLAND et al., 1998)] in preantral follicles furnishes the hypothesis, that steroids are of importance in the process of follicular development.

The enzyme aromatase cytochrome P450, as a product of the Cyp 19 gene, is responsible for a key event (SIMPSON et al., 1994) of "aromatization" in the process of estradiol synthesis. Its expression, therefore, is directly proportional to the ability of the follicle for estradiol synthesis.

The measurement of aromatase activity in individual follicles is possible by means of a modified estradiol production assay (FEHRENBACH et al., 1998; PÖHLAND et al., 1998; YUAN and GIUDICE, 1999; SMITZ et al., 1998). It is possible to carry out quantitative examinations with this assay, but the exact site of synthesis cannot be pinpointed in the follicle (oocyte, different somatic cell layers). Since a histochemical detection of the produced estradiol wouldn't provide any information about the site of synthesis due to the strong dislocation of the steroid, the same can be carried out by a detection of the key enzyme. In principle this is possible by an immunohistochemical way or by means of detection of gene expression. By the successful isolation of the bovine Cyp 19 gene (VANSELOW and FÜRBAß, 1995; FÜRBAß et al., 1997) the prerequisites for mRNA detection can be laid out.

The composition of the culture media is decisive for the developmental capability of follicles in the in vitro culture. Particularly fetal calf serum (FCS) represents a very complex mixture of different biologically active substances in contrast to a serum substitute like insulin-transferin-sodiumselenit (ITS). More precise knowledge about the effectiveness of media supplements is required for an optimization of the in vitro gametogenesis.

The objective of the study was to determine the prerequisites for the occurrence of the aromatase activity in vitro and to study the influence of FSH, if any, on the same. 
Animals

\section{Methods}

Dairy heifers from a commercial slaughter house were used. The ovaries were removed immediately after slaughter and transported on ice to the laboratory.

Follicle preparation and culture

Bovine ovaries, stored in PBS until processing, were dissected in small pieces and transferred to dishes with PBS on ice. The preantral and early antral follicles were mechanically isolated from tissue pieces using fine sharp needles and a binocular microscope. The follicles were recovered from the medium (PBS) by pipette and transferred to culture vessels. The follicles were cultivated individually $\left(5 \% \mathrm{CO}_{2}, 37\right.$ ${ }^{\circ} \mathrm{C}, 72 \mathrm{~h}$ ) in 24-well microwell culture dishes (NUNC).

Three types of medium were used: group FCS: $400 \mu$ RPMI without phenol red, with $10 \%$ FCS (v/v), $10^{-7} \mathrm{M}$ androstenedione, $1 \mu \mathrm{g} / \mathrm{ml}$ insulin, $100 \mathrm{IU} / \mathrm{ml}$ penicillin and $0.1 \mathrm{mg} / \mathrm{ml}$ streptomycin; group ITS: $400 \mu \mathrm{l}$ RPMI without phenol red, with $10^{-7} \mathrm{M}$ androstenedione, $1 \mu \mathrm{g} / \mathrm{ml}$ insulin, $2.5 \mu \mathrm{g} / \mathrm{ml}$ transferrin, $4 \mathrm{ng} / \mathrm{ml}$ Na-selenit, $100 \mathrm{IU} / \mathrm{ml}$ penicillin and 0.1mg/ml streptomycin; and group McCoy (GUTIERREZ et al., 2000): $400 \mu \mathrm{l}$ McCoy's 5a with bicarbonate, $20 \mathrm{mM}$ Hepes, 3mM L-glutamine, 0.1\% BSA (w/v), $10^{-7} \mathrm{M}$ androstenedione, $1 \mu \mathrm{g} / \mathrm{ml}$ insulin, $2.5 \mu \mathrm{g} / \mathrm{ml}$ transferrin, $4 \mathrm{ng} / \mathrm{ml} \mathrm{Na-}$ selenit, $100 \mathrm{IU} / \mathrm{ml}$ penicillin and $0.1 \mathrm{mg} / \mathrm{ml}$ streptomycin.

FSH was added to the culture medium in concentration of $0,0.125,0.25,0.5$ and 1 $\mathrm{IU} / \mathrm{ml}$ respectively.

Measurement of follicle diameter, growth and viability

The diameter, growth and viability of follicles $(n=24$ per medium, FSH concentration and follicular size $(<100 \mu \mathrm{m}, 100-200 \mu \mathrm{m}, 200-300 \mu \mathrm{m}, 300-400 \mu \mathrm{m},>400 \mu \mathrm{m}))$ were measured using an image analysing system based on an inverted microscope (Diaphot 200, Nikon), video camera (C5310, Hamamatsu), frame grabber (Grabbit PCI, SIS, Muenster), and an PC based image analysing software (AnalySIS 3.2, SIS, Muenster). Pictures (1024 x 1024 ppi, 24 bit colour) of all follicles at the beginning of the in vitro culture and after $72 \mathrm{~h}$ of cultivation were captured and stored in an image database. The diameter in the horizontal and in the vertical direction was interactively measured by AnalySIS. Using this data, the mean diameter and the follicular volume was calculated. The growth (volume) of follicles in in vitro culture was expressed as a percentage of that found at the beginning of the culture. Morphologically intact follicles with positive growth were classified as viable. The antrum formation and the structure of follicular growth in culture were examined using a stereo-microscope. Pictures were captured as described above.

\section{Steroid measurement}

Estradiol $_{17 \beta}\left(\mathrm{E}_{2}\right)$ and progesterone $(\mathrm{P})$ were measured in the supernatants by RIA ( $\mathrm{n}=8$ per medium, FSH concentration and follicular size $(<100 \mu \mathrm{m}, 100-200 \mu \mathrm{m}, 200-300 \mu \mathrm{m}$, 300-400 $\mu \mathrm{m},>400 \mu \mathrm{m})$ ).

The estimation of $\mathrm{E}_{2}$ was performed by a ${ }^{3} \mathrm{H}$ - RIA after extraction by diethylether. The main components of RIA were $2,4,6,7-{ }^{3} \mathrm{H}$ - estradiol (Amersham) as tracer, pure $\mathrm{E}_{2}$ (Jena-Pharm) as standard hormone and an antibody against an estradiol-6-CMOBSA conjugate raised in rabbits. This conjugate was further purified by HPLC and used at a titre of 1:55.000. After two incubation steps $\left(30 \mathrm{~min} 37^{\circ} \mathrm{C}\right.$ and $120 \mathrm{~min} 4$ 
${ }^{\circ} \mathrm{C}$ ) the $\mathrm{B} / \mathrm{F}$ separation was performed by the dextran-charcoal method. Counting of radioactivity was made by a LSC with integrated RIA program (Rackbeta 1219, Wallac, Finland).

The analysis of $\mathrm{P}(\mathrm{n}=8$ per medium, FSH concentration and follicular size $(<100 \mu \mathrm{m}$, $100-200 \mu \mathrm{m}, 200-300 \mu \mathrm{m}, 300-400 \mu \mathrm{m},>400 \mu \mathrm{m})$ ) was performed by a direct ${ }^{3} \mathrm{H}$ - RIA with $1,2,6,7-{ }^{3} \mathrm{H}$ - progesterone (Amersham) as tracer, pure $\mathrm{P}$ as standard and a rabbit antibody against progesterone-11-hemisuccinate-BSA purified by HPLC (titre 1:200.000). Incubations, B/F separation and counting were accomplished as described for estradiol.

\section{SDS-PAGE and Western Blotting}

To analyse follicles for their expression of aromatase, a pool of five follicles each, depending on follicle size $(<100 \mu \mathrm{m}, 100-200 \mu \mathrm{m}, 200-300 \mu \mathrm{m}, 300-400 \mu \mathrm{m},>400 \mu \mathrm{m})$ and culture medium, after $72 \mathrm{~h}$ of culture were analysed by Western Blotting (3 repetitions). Therefore the follicles were collected by centrifugation (5000g, $10 \mathrm{~min}$ ), lysed in $10 \mu \mathrm{l}$ of SDS-sample buffer and denaturated by boiling for two minutes. Then SDS-PAGE was performed according to Laemmi on $12,5 \%$ gels, where the acrylamid/bisacrylamide ratio was 30:0.8.

After the electrophoresis, proteins were transferred to PVDF membranes (Millipore) using the method of Towbin with a semi-dry blotting apparatus $\left(1 \mathrm{~mA} / \mathrm{cm}^{2}, 1\right.$ hour $)$. Thereafter, the membranes were saturated with $5 \%$ fat-free dry milk in TTBS overnight at $4^{\circ} \mathrm{C}$ under permanent agitation. After repeated washing with TTBS, the blots were incubated with a polyclonal antibody to aromatase (DPC, Biermann) for three hours at room temperature in TTBS containing 5\% BSA. The dilution of the antibody was 1:3000. The blots were then washed three times with TTBS and incubated with a HRP conjugated secondary antibody (anti rabbit, Santa Cruz). This antibody was diluted 1:5000 in TTBS. After a final washing in TTBS, the bands were visualized on X-ray films (Kodak), using a chemiluminescent kit (Amersham) according to the manufacturer's instruction.

Immunohistochemistry

An immunoperoxydase technique using a polyclonal antiboby to aromatase (DPC, Biermann) was executed. Briefly, follicles, fresh isolated or after culture $(n=4$ per medium and follicular size $(<100 \mu \mathrm{m}, 100-200 \mu \mathrm{m}, 200-300 \mu \mathrm{m}, 300-400 \mu \mathrm{m}$, $>400 \mu \mathrm{m})$ ), were fixed individually in Bouins mixture for 2 hrs. After dehydration in increasing ethyl-alcohol concentrations the follicles were embedded in paraffin and sliced with $5 \mu \mathrm{m}$ thickness. After de-paraffination, the endogenous peroxydase activity was blocked by $\mathrm{H}_{2} \mathrm{O}_{2}(1 \%, 30 \mathrm{~min})$. The cell membranes were permeabilized by Trypsin and the unspecific binding was blocked by $20 \%$ horse serum. The polyclonal antibody was incubated $(1: 1000)$ overnight at $4^{\circ} \mathrm{C}$. After washing, the second antibody (anti rabbit Biotin, 1:1000) was incubated for $1 \mathrm{~h}$ at $37^{\circ} \mathrm{C}$. Streptavidin-POD was added for $40 \mathrm{~min}$ at room temperature and after washing, the DAB-staining was carried out for 10 min under visible control. The slides were washed and covered and the examination was performed using a microscope and image analysing system as described above.

Realtime PCR

Total RNA (100 pooled follicles per medium and follicular size $(<100 \mu \mathrm{m}, 100$ $200 \mu \mathrm{m}, 200-300 \mu \mathrm{m}, 300-400 \mu \mathrm{m},>400 \mu \mathrm{m}), 2$ repetitions) was prepared with the 
RNeasy mini kit (Qiagen, Hilden, Germany). Briefly, cultured or freshly isolated follicles were lysed in 10 to $20 \mu \mathrm{l}$ of a guanidine iso-thiocyanate containing buffer and subjected to an additional homogenisation step using QIAshredder ${ }^{\mathrm{TM}}$ Homogenisers (Qiagen). Subsequently, one volume of $70 \%$ ethanol was added to the homogenized lysates and the RNA was extracted from the samples by adsorption to silica-gel spin columns. After three washing steps and elution in 15 to $30 \mu \mathrm{l}$ deionised, RNAse free water (washing buffers and water provided with the kit) RNA was quantified in a GeneQuant II instrument (Pharmacia, Freiburg, Germany).

For cDNA synthesis $1 \mu \mathrm{g}$ total RNA was reversely transcribed in $25 \mu \mathrm{l}$ reaction volume using M-MLV Reverse Transcriptase, RNase H Minus, Point Mutant (Promega, Mannheim, Germany) with two different reverse primers binding to transcripts of Cyp19 and of the Glyceraldhyde 3-Phosphate Dehydrogenase gene (GAPDH) respectively. All primers used for reverse transcription (RT) and real-time PCR (Tab. 1) were derived from published sequences of both genes (BTAROCG, EMBL/GenBank accession number Z32741 and BTGAPDH, EMBL/GenBank accession number AJ000039). The freshly synthesized cDNA samples were cleaned using the High Pure PCR Product Purification Kit (Roche, Mannheim, Germany) and eluted in $100 \mu$ l elution buffer.

For real-time PCR, 2 and $4 \mu \mathrm{l}$ of the purified cDNA were amplified with the LightCycler-FastStart DNA Master SYBR Green I Kit (Roche) in 10 $\mu$ l total reaction volume. Amplification and quantification of generated products were performed in a LightCycler instrument (Roche) under the following cycling conditions: Preincubation at $95^{\circ} \mathrm{C}$ for $10^{\prime}$, followed by 40 cycles denaturation at $95^{\circ} \mathrm{C}$ for $15^{\prime \prime}$, annealing at $60^{\circ} \mathrm{C}$ for $10^{\prime \prime}$, extension at $72^{\circ} \mathrm{C}$ for $10^{\prime \prime}$ and single point fluorescence acquisition at $83^{\circ} \mathrm{C}$ for $6^{\prime \prime}$.

The melting peaks (mp) of all samples were routinely determined by melting curve analysis in order to ascertain that only the expected products had been generated. Additionally, molecular sizes of PCR products from randomly selected samples were monitored by agarose gel electrophoresis analysis (3\% agarose, ethidium bromide stained). Melting peaks and sizes of PCR products derived from Cyp19 and GAPDH are shown in the Table.

Table

Primer sequence, size and melting peaks of light cycler samples (Primer-Sequenz, Größe und Schmelzpunkt der Proben für den Light-Cycler)

\begin{tabular}{l|lllcc}
\hline & Forward primer & Reverse primer & RT primer & size (bp) & mp $\left({ }^{\circ} \mathbf{C}\right)$ \\
\hline Cyp19 & GAAGTGCTGAACCCAAGGCATTAC & AATGAGGGGCCAATTCCCAGA & GAGCATGTTAGAGGTGTCCAGCA & 171 & 85 \\
GAPDH & CAGTCTTCTGGGTGGCAGTGATG & CAGGAGGCATTGCTGACAATCTTG & TACATGGTCTACATGTTCCAGTATG & 332 & 88 \\
\hline
\end{tabular}

To generate external standard curves for each run, different concentrations (2 x 10-17 to $2 \times 10-13 \mu \mathrm{g}$ DNA/ $\mu \mathrm{l}$ ) of PCR products of both genes, cloned into GEM-T plasmid vector, were co-amplified with the same primer pairs. Fluorescence signals, which were recorded on-line during amplification, were subsequently analysed using the "Second Derivative Maximum" method of the LightCycler Data Analysis software. Copy numbers were calculated relative to the amount of total RNA.

Statistical analysis

The data obtained from individual follicles were classified according to follicular diameter. Four classes were formed: Group1: <40 $\mu \mathrm{m}$, group2: 40-100 $\mu \mathrm{m}$, group3: 100-200 $\mu \mathrm{m}$ and group4: 200-300 $\mu \mathrm{m}$. Data were expressed as mean \pm S.D. Pairwise 
comparisons between treated follicles and the corresponding controls without additives were performed, using one-factor analysis of variance (ANOVA) and with Student Newman-Keuls-test (SAS) to determine significant differences $(p<0.05)$.

\section{Results}

The number of recovered follicles was approximately $37 \pm 21$ per ovary depending on the quality of the ovary. The viability of follicles was tested by measuring the relative growth after $72 \mathrm{~h}$ of incubation and by morphological estimation. Approximately $63 \pm$ $24 \%$ of all follicles were growing. The morphological inspection provided evidence of the beginning of antrum formation in follicles larger than $300 \mu \mathrm{m}$ diameter (data not shown).
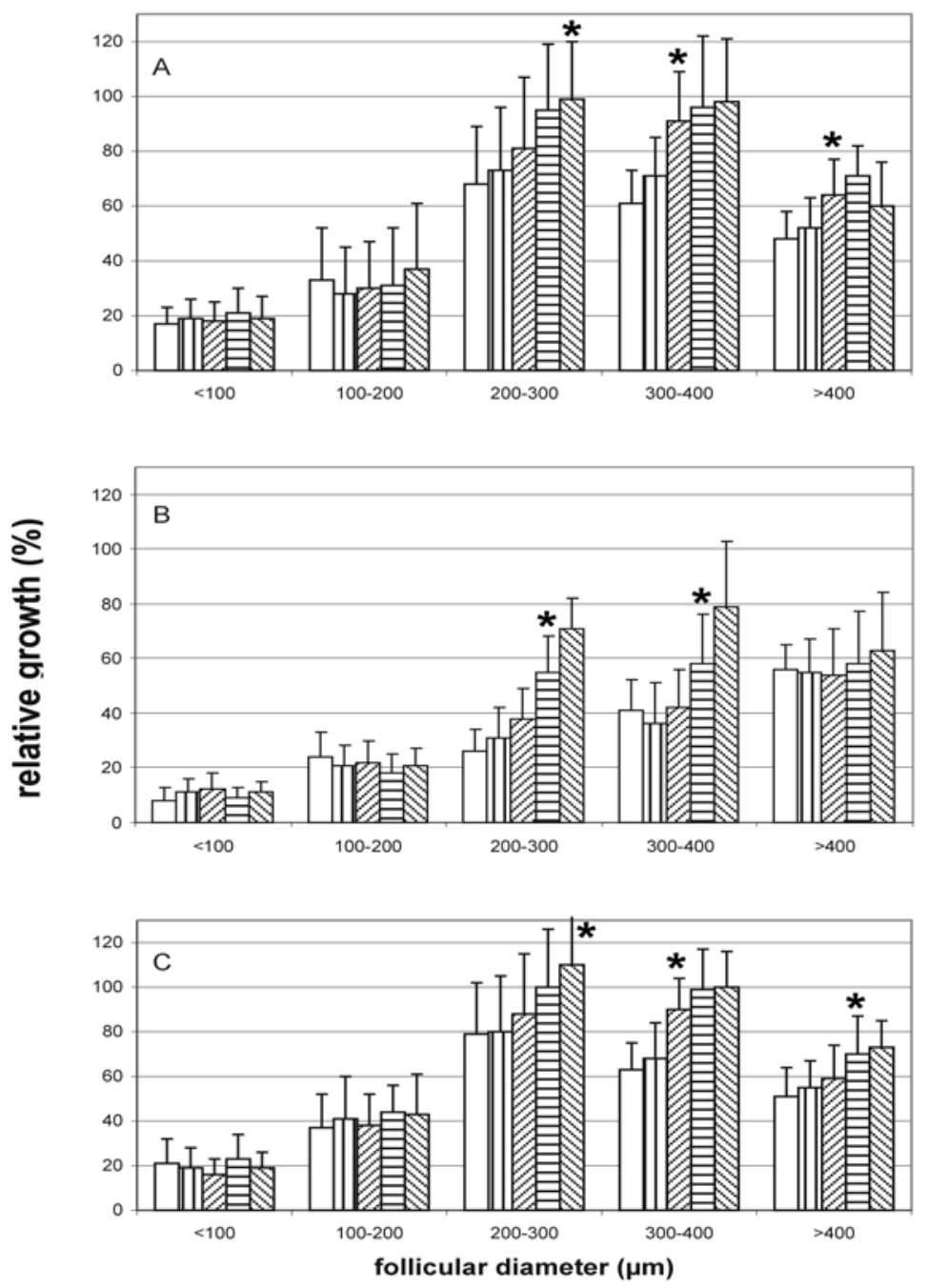

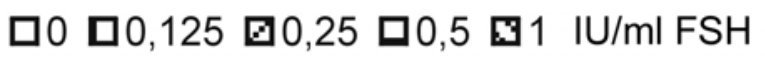

Fig. 1: Influence of increasing doses of recombinant human FSH (see legend) on follicular growth in in vitro culture $(72$ h) depending on follicular diameter and culture medium (A: FKS, B: ITS, C: McCoy). The percentage of growth was calculated in relation to the follicular diameter at the beginning of culture. The asterisk indicates the minimal effective dose of FSH $(\mathrm{p}<0.05)$ (Der Einfluss ansteigender Dosen rekombinanten humanen FSH (siehe Legende) auf das Follikelwachstum in In-vitro-Kultur (72h) in Abhängigkeit vom Follikeldurchmesser und dem Kulturmedium (A: FKS, B: ITS, C: McCoy). Das Wachstum wurde prozentual im Verhältnis zum Follikeldurchmesser zum Beginn der Kultivierung berechnet. Der Stern markiert die minimale effektive FSH-Dosis $(\mathrm{p}<0,05))$ 
The influence of culture medium, FSH and follicular diameter on the growth of follicles is shown in Figure 1. A total number of 1243 follicles was tested, 10-15 per follicle group, for different medium and hormone concentrations. The growth was expressed as a percentage in relation to the diameter at the beginning of culture. All tested follicles were evaluated. There was no effect of FSH on follicles smaller than $200 \mu \mathrm{m}$. The growth of follicles cultured in ITS medium was significantly lower. In contrast, the growth in McCoy's medium tended to be greater but not significantly higher in relation to the FCS medium.

The effective dose of FSH was approximately 0.5-1 IU/ml for follicles with 200-300 $\mu \mathrm{m}$ diameter and $0.25-0.05 \mathrm{IU} / \mathrm{ml}$ for follicles $>300 \mu \mathrm{m}$ diameter. The relative growth was the highest in follicles between 200 and $400 \mu$ m diameter.

The steroid synthesis was measured separately for each viable follicle tested for growth (see above). The results are shown in Figure 2.
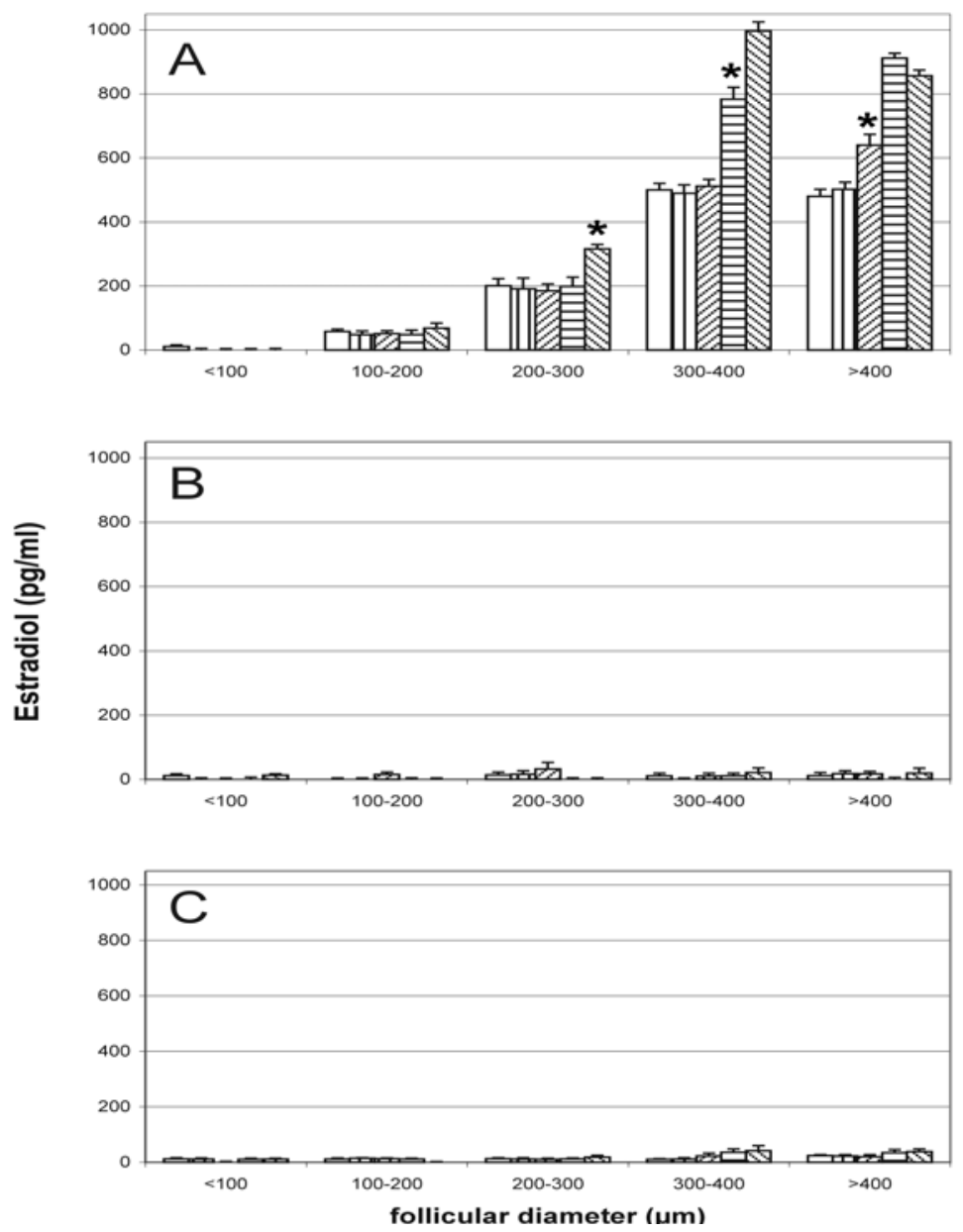

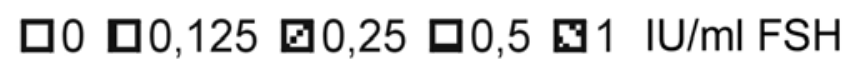

Fig. 2: Influence of increasing doses of recombinant human FSH (see legend) on estradiol 17 synthesis in in vitro culture (72 h) depending on follicular diameter and culture medium (A: FKS, B: ITS, C: McCoy). The asterisk indicates the minimal effective dose of FSH $(\mathrm{p}<0.05)$ (Der Einfluss ansteigender Dosen rekombinanten humanen FSH (siehe Legende) auf die Estradiol ${ }_{17}$-Synthese in In-vitro-Kultur (72h) in Abhängigkeit vom Follikeldurchmesser und dem Kulturmedium (A: FKS, B: ITS, C: McCoy). Der Stern markiert die minimale effektive FSH-Dosis $(\mathrm{p}<0,05))$ 
Only follicles cultured in FCS medium produced significant amounts of estradiol. No estradiol synthesis was measurable for follicles cultured in ITS or McCoy's medium. Under FCS conditions, follicles $>100 \mu \mathrm{m}$ diameter showed a basal estradiol production. For follicles between 200 and $300 \mu \mathrm{m}$ diameter 1IU/ml FSH stimulated the estradiol production significantly. Larger follicles (300-400 $\mu \mathrm{m}$ diameter) reacted to $0.5 \mathrm{IU} / \mathrm{ml}$ and $0.25 \mathrm{IU} / \mathrm{ml}$ ( $>400 \mu \mathrm{m}$ diameter) with significant increase in estradiol synthesis.

The western blot (Figure 3) demonstrates significant bands in the $56 \mathrm{kDa}$ area only for follicles cultured in FCS medium (lane E-H).

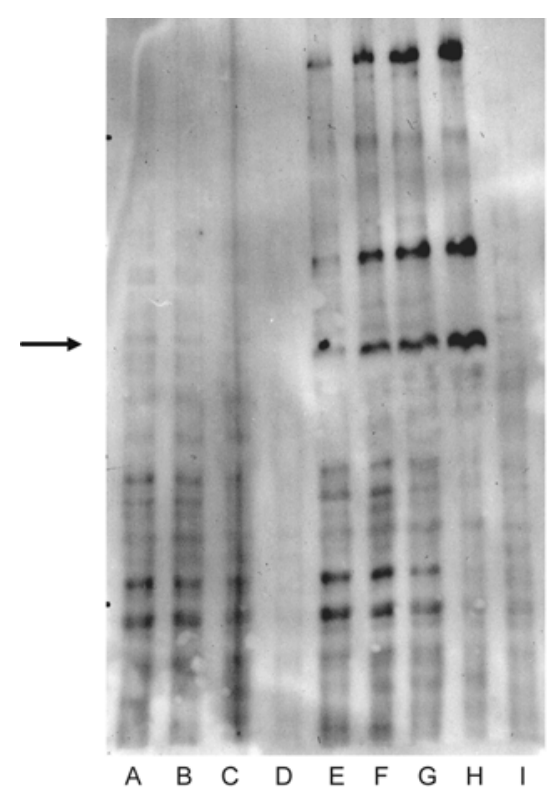

Fig. 3: Detection of aromatase by western blotting depending on culture medium and follicle size. The arrow indicates the aromatase by $56 \mathrm{kDa}$ molecular weight (A: ITS medium $>400 \mu \mathrm{m}$, B: McCoy medium $>400 \mu \mathrm{m}$, C:

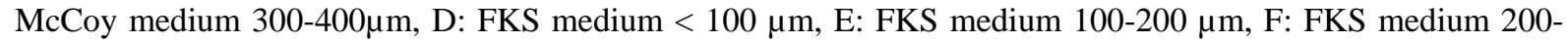
$300 \mu \mathrm{m}$, G: FKS medium 300-400 $\mu \mathrm{m}$, H: FKS medium $>400 \mu \mathrm{m}$, I: fresh isolated $>400 \mu \mathrm{m}$ ) (Bestimmung der Aromatase in Abhängigkeit vom Kulturmedium und der Follikelgröße mittels Western-Blot. Der Pfeil markiert die Aromatase mit einem Molekulargewicht von $56 \mathrm{kDa}$ (A: ITS-Medium >400 $\mu \mathrm{m}$, B: McCoy-Medium $>400$

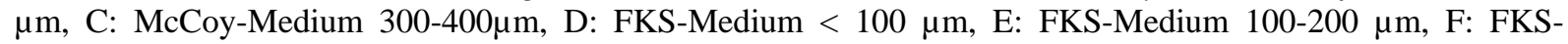

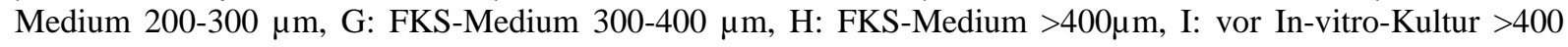
$\mu \mathrm{m})$ )

For follicles cultured in ITS or McCoy's medium or for uncultivated follicles measured directly after preparation no aromatase correlated bands were visible. It is obvious from figure 4 that the even distribution of aromatase in the follicle can be proved by immunohistochemistry. The illustration shows an example of a follicle after culture in FCS medium to a size of 300-400 $\mu$ m diameter.

The results of realtime PCR correspond to the findings of western blotting. Significant amounts of mRNA were measured only in follicles larger than $200 \mu \mathrm{m}$ diameter after cultivation in FCS medium (Figure 5). 

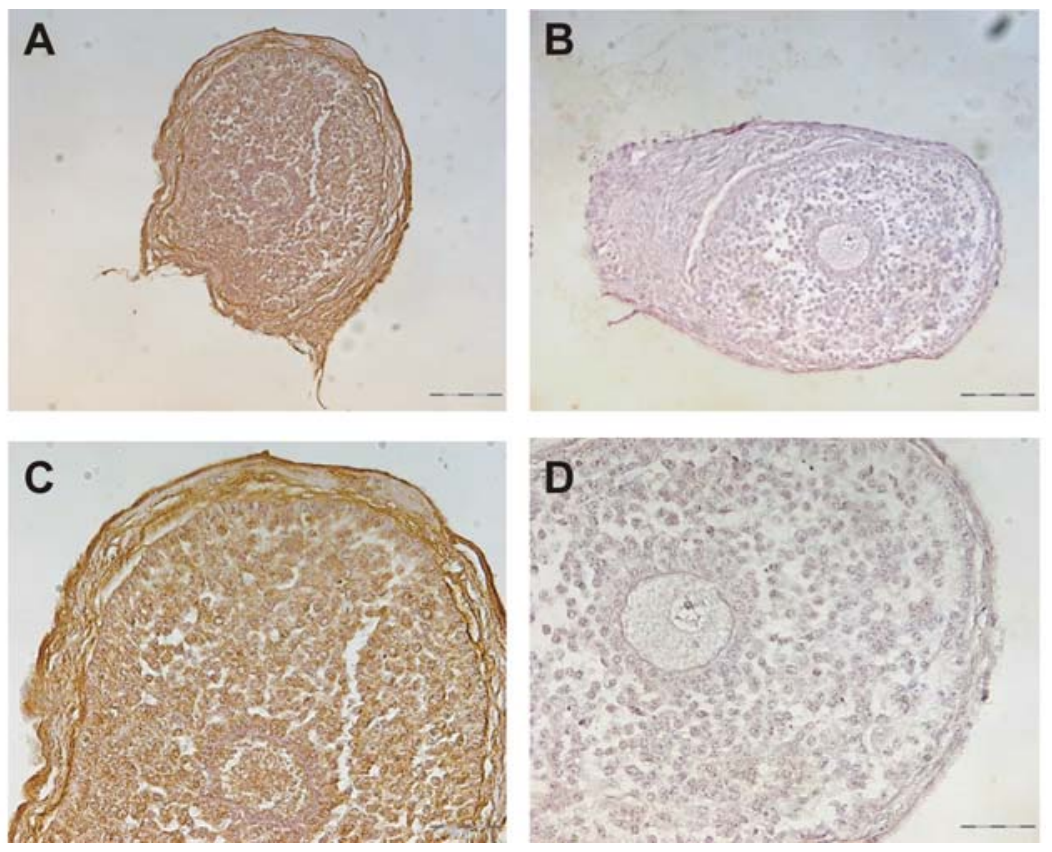

Fig. 4: Immunohistochemical aromatase staining of a follicle with 300-400 $\mu \mathrm{m}$ diameter (A: stained follicle, bar $=100 \mu \mathrm{m} ; \mathrm{B}$ : control, bar $=100 \mu \mathrm{m} ; \mathrm{C}$ : stained follicle, bar $=50 \mu \mathrm{m} ; \mathrm{D}$ : control, bar $=50 \mu \mathrm{m})$ (Immunhistochemische Färbung der Aromatase in einem Follikel mit 300-400 $\mu \mathrm{m}$ Durchmesser (A: gefärbter Follikel, Balken $=100 \mu \mathrm{m}$; B: Kontrolle, Balken $=100 \mu \mathrm{m}$; C: gefärbter Follikel, Balken $=50 \mu \mathrm{m}$; D: Kontrolle, Balken $=50 \mu \mathrm{m})$ )

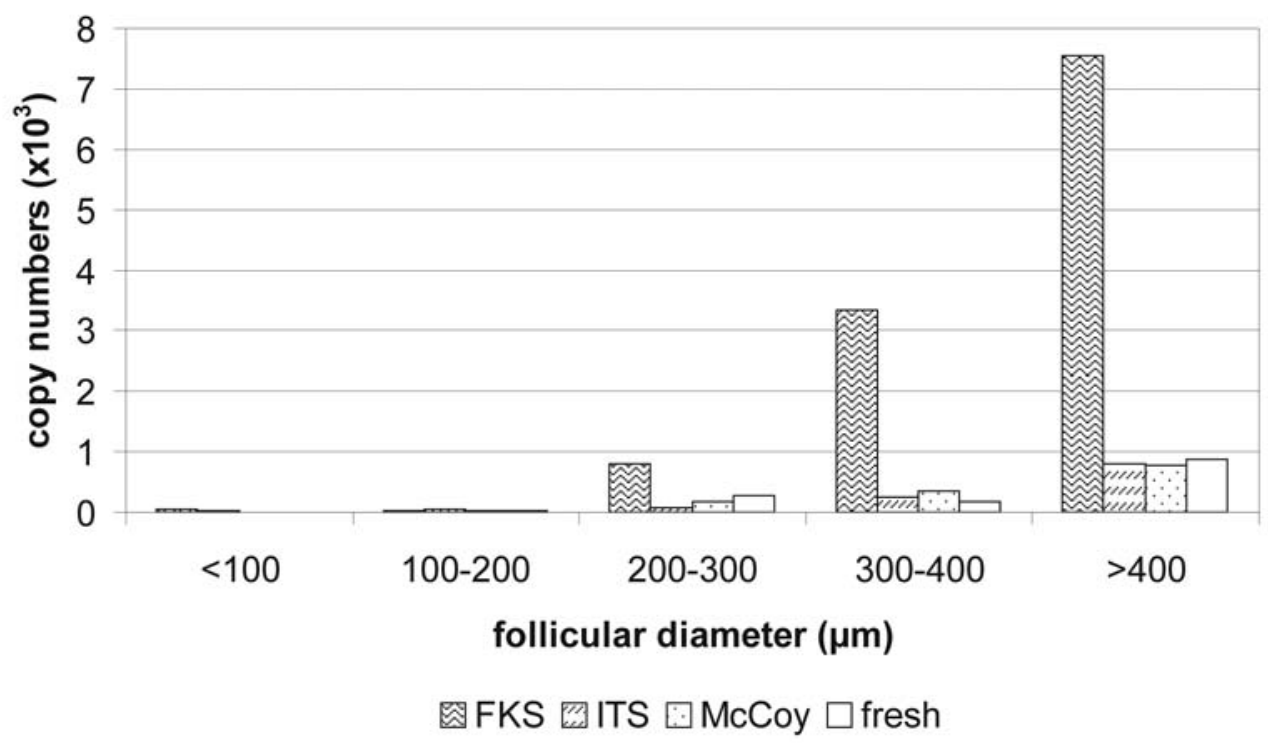

Fig. 5: Copy numbers of Cyp 19 specific mRNA (aromatase), calculated relative to the amount of total RNA depending of follicular diameter and culture medium (see legend) (Anzahl der Kopien Cyp 19 spezifischer mRNA (Aromatase) berechnet in Relation zur Gesamt-RNA in Abhängigkeit vom Follikeldurchmesser und dem Kulturmedium (siehe Legende))

\section{Discussion}

The comparison of different media showed that the growth of the follicles is not affected if McCoy's medium is used instead of FCS medium. This result is in agreement with statements of the group of Guttierez (GUTTIEREZ et al., 2000). Unlike this the growth tended to decrease when the FCS in the FCS medium was 
substituted only by ITS. It seems that this modified McCoy's medium (GUTTIEREZ et al., 2000) is more suitable for a follicle culture.

There was no significant effect of FSH on growth of follicles smaller than $200 \mu \mathrm{m}$ in diameter. These results correspond to the hypothesis that the first stages of follicular development are gonadotropin-independent (IRELAND, 1987). TISDALL et al. (1995) found that the FSH receptor gene is not expressed during the earliest stages of follicle growth (sheep). In contrast some authors [e.g. (WRIGHT et al., 1999)] described that small follicles (human) are responsive to FSH. It may be possible that intraovarian growth factors play an important role during this phase (NAYUDU and OSBORNE, 1992; HULSHOF, 1994). Obviously, more research is required to define the role of FSH on early stages of folliculogenesis (GREENWALD and ROY, 1994). The follicular growth was stimulated by FSH in a dose dependent manner in larger follicles. Since the influence of FSH on proliferation of granulosa cells is a receptor mediated process activating the cAMP cascade (YONG et al., 1992), the results may hint towards the functionally expressed FSH receptors and the corresponding signal transduction system at this follicular stage. These findings are in accordance to observations of WANDJI et al. (1996). In their experiments, the addition of $50 \mathrm{ng} / \mathrm{ml}$ FSH stimulated the growth of follicles between $60-180 \mu \mathrm{m}$. In contrast, WANG and GREENWALD (1993) found a stimulatory effect of FSH only on the growth of antral follicles in mice. The conjecture of species-specific differences is supported by the detection of mRNA for FSH receptors in ovine preantral follicles with two and more layers of granulosa cells by in situ hybridisation (TISDALL et al., 1995). FSH receptors were detected in early stages of hamster follicles by autoradiography (ROY et al., 1987). An FSH receptor expression in bovine follicles is also possible in early stages of development, but physiological effects of growth stimulation require a maturation of specific transduction system and enzyme cascades additionally.

The results of the estradiol synthesis measurement show that amongst all the tested follicle size classes, estradiol synthesis took place only by using medium containing FCS. It cannot be blamed on bad culture conditions since survival and growth of the follicles occurred in all media. As described above, the growth rates were highest in the McCoy's medium. The results of western blotting as well as the realtime PCR show that aromatase is expressed only after cultivation in the FCS medium and is available as an enzyme. No aromatase or mRNA was detectable after culture in other media. Since no aromatase or mRNA was detectable in freshly isolated follicles without cultivation, it must be assumed that there are biological active compounds in the FCS which lead to an induction of aromatase expression in vitro. Which component of the FCS causes this effect is not clear. Steroids are probably not the cause because the FCS was adsorbed to charcoal. No more steroids (estradiol ${ }_{17 \mathrm{\beta}}$, progesterone) could be measured in the FCS medium either. Androstenedione was available in all media as additive.

It remains unclear whether induced aromatase expression has positive impact on the follicular development in vitro. Recent examinations of follicles of the pig (WU et al., 2001) show that a certain concentration of a homologous serum is necessary for the development of the follicles in the culture medium. Presumably, it may lead to further changes in the expression pattern of the follicle cells. A recording of these changes will surely be very meaningful and should be carried out in future. Attempts must be made to determine the components of the FCS which cause these changes in the 
expression pattern. The use of potential candidates in serum free media may bring us closer to the solution.

\section{Acknowledgment}

This work was supported by a grant from the Deutsche Forschungsgemeinschaft (DFG Po 540/4-1).

ADASHI, E.Y.:

\section{References}

The intraovarian insuline-like growth factor system. in: ADASHI, E.Y.; LEUNG, P.C.K. (eds): The ovary, Raven Press, New York (1993), 319-337

EPPIG, J.J.; O'BRIEN, M.J.; PENDOLA, F.L.; WATANABE, S.:

Factors affecting the developmental competence of mouse oocytes grown in vitro: follicle-stimulating hormone and insulin. Biol. Reprod., 59 (1998), 1445-1453

EPPIG, J.J.; SCHROEDER, A.C.:

Capacity of mouse oocytes from preantral follicles to undergo embryogenesis and development to live young after growth, maturation and fertilization in vitro. Biol. Reprod., 41 (1989), 268-276

FEHRENBACH, A.; NÜSSE, N.; NAYUDU, P.L.:

Patterns of growth, oestradiol and progesterone released by in vitro cultured mouse ovarian follicles indicate consecutive selective events during follicle development. J. Reprod. Fertil., 113 (1998), 287297

FINDLAY, J.K.:

An Update on the Roles of Inhibin, Activin and Follistatin as Local Regulators of Folliculogenesis. Biol. Reprod., 48 (1993), 15-23

FÜRBAß, R.; KALBE, C.; VANSELOW, J.:

Tissue specific expression of the bovine aromatase encoding gene uses multiple transcriptional start sites and alternative first exons. Endocrinology, 138 (1997), 2813-1819

GELETY, T.J.; MAGOFFIN, D.A.:

Ontogeny of steroidogenic enzyme gene expression in ovarian theca-interstitial cells in the rat: regulation by a paracrine theca-differentiating factor prior to achieving luteinizing hormone responsiveness. Biol. Reprod., 56 (1997), 938-945

GREENWALD, G.S.; ROY, S.K.:

Follicular development and its control. in: KNOBIL, E.; NEILL, J.D. (eds): Physiology of Reproduction. Raven Press, New York (1994), 629-725

GUTIERREZ, C.G.; RALPH, J.H.; TELFER, E.E.; WILMUT, I.; WEBB, R.:

Growth and antrum formation of bovine preantral follicles in long-term culture in vitro. Biol. Reprod., 62 (2000), 1322-1328

HARRISON, R.J.; WEIER, B.J.:

Structure of the mamalian ovary. In: ZUCIMAN, S.; WEIER, B.H.J. (eds.): The Ovary: General Aspects. Vol. 1, 2nd ed., Academic Press, New York (1977), 113-218

HULSHOF, S.C.J.: Bovine preantral follicles and their development in vitro. Thesis, 1994

IRELAND, J.J.:

Control of follicular growth and development. J. Reprod. Fert., 34 (1987), 39-54

KANITZ, W.:

Follicular dynamic and ovulation in cattle - a review. Arch Tierz., Dummerstorf 46 (2003), 187-198

KANITZ, W.; BRÜSSOW, K.-P.; BECKER, F.; TORNER, H.; SCHNEIDER, F.; KUBELKA, M.; TOMEK, W.:

Comparative aspects of follicular development, follicular and oocyte maturation in cattle and pigs. Arch. Tierz., Dummerstorf 44 (2001), 9-23

KOERING, M.J.; DANFORTH, D.R.; HODGEN, G.D.:

Early follicle growth in the juvenile macaca monkey ovary: the effects of estrogen priming and folliclestimulating hormone. Biol. Reprod., 50 (1994), 686-694

LUSSIER, J.P.; MATTON, P. ; DUFOUR, J.J.:

MIHM, M.: Growth rates of follicles in the ovary of the cow. J. Reprod. Fert., 81 (1987), 301-307

Intrafollicular health markers during antral follicle wave development in cattle. Arch. Tierz., Dummerstorf 44 (2001), 24-29

NAYUDU, P.L.; OSBORNE, O.S.: 
Factors influencing the rat of preantral and antral growth of mouse ovarian follicles in vitro. J. Reprod. Fertil., 95 (1992), 349-362

PÖHLAND, R.; STENZEL, V.; ALM, H.; KATSKA, L.:

The influence of FSH on viability, growth and steroid synthesis of bovine preantral follicles in different stages of differentiation in vitro. J. Reprod. Fert., Abstract Series 21 (1998), 8

REVELLI, A.; PACCHIONI, D.; CASSONI, P.; BUSSOLANTI, G.; MASSOBRIO, M.:

In situ hybridization study of messenger RNA for estrogen receptor and immunohistochemical detection of estrogen and progesterone receptors in the human ovary. Gynecol. Endocrinol., 10 (1996), 177-186

ROY, S.K.; WANG, S.C.; GREENWALD, G.S.:

Radioreceptor and autoradiographic analysis of FSH, HCG, and prolactin binding sites in primary to antral hamster follicles during the periovulatory period. J. Reprod. Fertil., 79 (1987), 307-313

ROY, S.K.; GREENWALD, G.S.:

Follicular development through preantral stages: signaling via growth factors. J. Reprod. Fertil., 50 (1996), 83-94

SIMPSON, E.R.; MAHENDROO, M.S.; MEANS, G.D.; KILGORE, M.W.; HINSHELWOOD, M.M.;

GRAHAM-LORENCE, S.; AMARNEH, B.; ITO, Y.; FISHER, C.R.; MICHAEL, M.D.:

Aromatase cytochrome P450, the enzyme responsible for estrogen biosynthesis. Endocr. Rev., 15 (1994), 342-355

SMITZ, J.; CORTVRINDT, R.; HU, Y.:

Epidermal growth factor combined with recombinant human chorionic gonadotrophin improves meiotic progression in mouse follicle-enclosed oocyte culture. Hum. Reprod., 13 (1998), 664-669

SPEARS, N.; BOLAND, N.I.; MURRAY, A.A.; GOSDEN, R.G.:

Mouse Oocytes Derived from in Vitro Grown Primary Ovarian Follicles Are Fertile. Hum. Reprod., 9 (1994), 527-532

SPEARS, N.; MURRAY, A.A.; ALLISON, V.; BOLAND, N.I.; GOSDEN, R.G.:

Role of gonadotrophins and ovarian steroids in the development of mouse follicles in vitro. J. Reprod. Fertil., 113 (1998), 19-26

TISDALL, D.J.; WATANABE, K.; HUDSON, N.L.; SMITH, P.; MCNATTY, K.P.:

FSH receptor gene expression during ovarian follicle development in sheep. J. Mol. Endocrinol., 15 (1995), 273-281

TOMANEK, M.; PISSELET, C.; MONGET, P.; MADIGOU, T.; THIEULANT, M.L.; MONNIAUX, D.: Estrogen receptor protein and mRNA expression in the ovary of sheep. Mol. Reprod. Dev., 48 (1997), 53-62

VANSELOW, J.; FÜRBAß, R.:

Novel aromatase transcripts from bovine placenta contain repeated sequence motifs. Gene, 154 (1995), 281-286

WANDJI, S.A.; EPPIG, J.J.; FORTUNE, J.E.:

FSH and growth factors affect the growth and endocrine function in vitro of granulosa cells of bovine preantral follicles. Theriogenology, 45 (1996), 817-832

WANG, X.N.; GREENWALD, G.S.:

Synergistic effects of steroids with FSH on folliculogenesis, steroidogenesis and FSH- and hCGreceptors in hypophysectomized mice. J. Reprod. Fertil., 99 (1993), 403-413

WRIGHT, C.S.; HOVATTA, O.; MARGARA, R.; TREW, G.; WINSTON, RM.; FRANKS, S.; HARDY, K.:

Effects of follicle-stimulating hormone and serum substitution on the in-vitro growth of human ovarian follicles. Hum. Reprod., 14 (1999), 1555-1562

WU, J.; EMERY, B.R.; CARRELL, D.T.:

In vitro growth, maturation, fertilization and embryonic development of oocytes from porcine preantral follicles. Biol. Reprod., 64 (2001), 375-381

YONG, E.L.; BAIRD, D.T.; YATES, R.; REICHERT, L.E.; HILLIER, S.G.:

Hormonal regulation of the growth and steroidogenic function of human granulosa cells. J. Clin. Endocrin. Metab., 74 (1992), 842-849

YUAN, W.; GIUDICE, L.C.:

Insulin-like growth factor-II mediates the steroidogenic and growth promoting actions of follicle stimulating hormone on human ovarian pre-antral follicles cultured in vitro. J. Clin. Endocrinol. Metab., 84 (1999), 1479-1482 